\title{
MISIUNEA BISERICII ÎN CONTEXTUL GEOPOLITIC EUROPEAN ACTUAL
}

Nicolae Brînzea*

\begin{abstract}
We are living in a world thirsting for contacts, appointments, understanding, harmony, unity and cooperation. People, nations and states wish to meet, to listen, to share experiences with each other and assess how much can they do together, and especially to heal existing wounds and build a sustainable peace. Nowadays, they set a lot of cultural exchanges, more than in any other period of history. Isolationism is increasingly condemned. It is recognized increasingly that it's more important what unites than what divides people between them.

There are factors which make the world increasingly resembles more of a global village. Enhance communications facility has contributed much to this.

TV, fax, internet and email are significant. Anthropological sciences, ethnological and religious recorded incredible progress. Awareness among people of mutual dependence and the need to build a harmonious world community has grown. Religions can not stand aside, must be present in this world. Those who follow them are called to meet, to try to understand eachother in a better way, to ask what they can do together to improve the world.
\end{abstract}

Keywords: mission, Church, Europe, unity, Christianity, ecumenism.

Trăim într-o lume însetată de contacte, întâlniri, înțelegere, armonie, unitate şi colaborare. Oameni, națiuni şi state doresc să se întâlnească, să se asculte, să împărtăşească experiențele unii cu alții şi să evalueze cât pot face împreună, şi mai ales să vindece rănile existente şi să construiască o pace cât mai durabilă. În zilele noastre, s-au stabilit o mulțime de schimburi culturale, mai multe decât în orice altă perioadă a istoriei. Izolaționismul este din ce în ce mai

\footnotetext{
* PhD, Assistant Professor, "Sf. Muceniță Filoteia" Faculty of Orthodox Theology at the University from Pitești.
} 
condamnat. Se recunoaşte din ce în ce mai mult că este mai important ceea ce uneşte decât ceea ce desparte oamenii între ei.

Există factori datorită cărora lumea se aseamănă din ce în ce mai mult unui stat global. Sporita facilitate a comunicațiilor a contribuit mult la aceasta.

Televiziunea, faxul, internetul şi poşta electronică sunt semnificative. Ştiinţele antropologice, etnologice şi religioase au înregistrat progrese incredibile. În rândul oamenilor creşte conştiinţa dependenței reciproce şi a necesității de a construi o comunitate mondială mai armonioasă. Religiile nu pot sta deoparte, trebuie să fie prezente în această lume. Cei ce le urmează sunt chemați să se întâlnească, să încerce să se înțeleagă mai bine, să se întrebe ce pot face împreună, spre a îmbunătăți lumea.

Credincioşii diferitelor religii sunt chemați să-şi unească mâinile pentru a promova acceptarea şi mărturisirea vinovăţiilor, căința, iertarea, împăcarea, iubirea şi unitatea. Adevărata religie învață că iertarea nu este semn de slăbiciune. Dumnezeu este Dumnezeul vieții şi al morții. Este Dumnezeul păcii şi nu al războiului.

În lume toți suntem frați, dar fiecare trece pe lângă celălalt ignorându-l. Multe sunt necesare în toate domeniile vieții şi toate sunt importante, dar dacă lipseşte iubirea, totul este zadarnic. Iubirea este într-adevăr inima Bisericii, iar dacă Biserica a biruit vreodată şi va mai birui, aceasta se întâmplă numai pentru că trăieşte iubirea:, Am înteles că Biserica are o inimă şi că această inimă este aprinsă de iubire. Am ințteles că numai iubirea face să acționeze mădularele Bisericii: am ințeles că iubirea cuprinde toate vocațiile, că iubirea este totul!",

Aici intervine misiunea specială a Bisericii, mai ales în contextul geopolitic european actual de căutare a diversității ca semn de deschidere față de darurile lui Dumnezeu, şi pentru a sprijini vocația şi misiunea Bisericii pe de o parte, dar şi de expansiune ca

${ }^{1}$ Sf. Tereza a Pruncului Iisus şi a Sfintei Fețe, Istoria unui suflet, Bucureşti, Ed. Pauline, 1998, p. 47. 
sferă de influență pe de altă parte, aspect periculos, ce creează anumite tensiuni în vecinătatea Europei, cu posibil impact catastrofal pe viitor. Biserica reiterează drumul Crucii ca drum al Păcii mondiale şi este singura capabilă să realizeze pacea biblică: „Pace vă las vouă, pacea Mea o dau vouă, nu precum dă lumea vă dau Eu. Să nu se tulbure inima voastră, nici să se înfricoşeze"( Ioan 14, 27).

În esență, orice reînnoire a Bisericii constă în mod esențial într-o fídelitate sporită față de vocația ei, acesta fiind şi motivul care explică misiunea Bisericii pentru mişcarea ecumenică către unitatea şi pacea mondială. Biserica în călătoria sa pe acest pământ este invitată să facă paşi majori pentru o continuă reformă de care are nevoie în misiunea sa, deoarece este o instituție divino-umană, fiind însuşi Trupul mistic al lui Iisus Hristos. Poate tocmai de aceea ecumenismul reprezintă acum, mai mult ca oricând, o modalitate eficientă în promovarea păcii şi a securităţii mondiale, mai ales pe fondul tensiunilor geopolitice actuale:,, ecumenismul este un serviciu ce-şi găseş̧te propria concretizare istorică în angajarea Bisericilor, de a-şi arăta caritatea şi comuniunea ca o colaborare pentru pacea, dreptatea şi libertatea popoarelor".2.

Adevărata reînnoire a Bisericii se dezvăluie prin unele aspecte care sunt comune şi anume: trebuiesc adunate toate valorile ce ne unesc şi puse în comun, pentru a păşi împreună spre comuniunea unităţii depline. Nu se poate face o adevărată unire căutând greşelile unei confesiuni sau ale alteia, ci punându-se de acord în acele valori creştine izvorâte din patrimoniul comun, pentru a se ajunge la o concluzie benefică pentru ambele părți: ,Mişcarea ecumenică este poate cel mai important şi mai nou element din istoria Bisericii secolului al XXI-lea"'.

Pe această linie dacă se merge, se poate vorbi de o reînnoire autentică de care vor avea de câş̧tigat şi unii şi alții. De aceea Biserica cea Una trebuie să rămână fermă în apărarea adevărului,

${ }^{2}$ G. Culla, L'ecumenismo, Torino, Ed. Simbolo, 1989, p. 193.

${ }^{3}$ R. Kottje - B. Moeller, Storia ecumenica della Chiesa, vol. III, Torino, Ed. Queriniana, 1981, p. 147. 
foarte clară şi atentă la dialogul ce priveşte pacea şi securitatea spațiului geopolitic european. Biserica nu este statică ci dinamică şi antrenantă, tinzând spre unitatea deplină astfel încât, să nu mai avem Biserici surori ci Biserica lui Hristos cea Una. Această reînnoire are o importanță ecumenică specială. Diferitele forme de trăire ale Bisericii, în care a luat ființă această reînnoire, ca de exemplu: mişcarea biblică şi liturgică, anunțarea cuvântului lui Dumnezeu, cateheza, apostolatul laic, diferite forme de viață consacrată, etc., sunt semne clare ale progresului pentru viitorul dialog ecumenic de promovare a păcii şi securități mondiale chiar în contextul geopolitic european actual.

Pentru a face ecumenism este de mare trebuinţă să cunoaştem starea, gândirea şi cultura fraţilor despărțiți. În acest sens este necesar studiul intens care la rândul său trebuie efectuat după adevăr şi cu bunăvoința reciprocă. Orgoliul nu face decât să dezbine şi mai mult antrenând $\mathrm{cu}$ sine posibile conflicte majore fără cale de întoarcere:,,De aceea dialogul teologic favorizează între creştini un ecumenism reciproc în cunoaşterea obiectivă ce comportă o schimbare bogată şi un discernământ ermeneutic, pentru fiecare tradiție eclezială, între ceea ce este prioritar şi fundamental şi ceea ce este consecvent, expresie istorică şi culturală "

Atenție sporită însă deoarece ,,drumul ecumenic se pare că ar fi alunecos şi plin de noi piedici". Dialogul devine astfel o misiune ecumenică esenţială a Bisericii şi chiar o obligație morală a acesteia față de provocările lumii moderne. Dialogul ecumenic şi misiunea Bisericii nu pot fi în mod exclusiv cu caracter teologic, deoarece ele trebuie să contribuie la transformarea mentalităţilor, a comportamentului existenţial „obişnuit” şi trebuie să tindă spre un raport constant de colaborare în mărturisirea credinței. Dialogul şi misiunea Bisericii tind către unitatea integrală care presupune darul

A. Zampi, L'Ecumenismo nel Concilio Vaticano II, Roma, Ed. Mediazione, 1987, p. 21.

${ }^{5}$ M. Matti, L'Ecumenismo fra est e o vest, în „Il Regno”, nr. 18 (1998), p. 122. 
liber şi creator al iubirii lui Dumnezeu ${ }^{6}$. Ele se fondează pe unicul Botez al creştinilor, pe darul Duhului Sfânt, pe credința hristologică, pe ascultarea Cuvântului şi pe viața eclezială.

Pentru a evita neînțelegerile, misiunea Bisericii în dialogul ecumenic cere o revizuire critică a limbajului teologic diferit, deoarece aceleaşi categorii iau diferite semnificaţii, deşi se referă la acelaşi conținut. Misiunea Bisericii vizează „,̂nțelegerea” stimei diversităților în unicul popor al lui Dumnezeu-poporul creştin, fără triumfalisme confesionale, motiv pentru care este necesară o deschidere reciprocă faţă de adevăr, atât din partea celui care îl propune, cât şi din partea celui care îl primeşte.

Limbajul care trebuie promovat în contextul geopolitic european actual este cel pozitiv, pentru că numai în acest mod pot fi depăşite rigidităţile polemicilor istorice şi se poate ajunge la elaborarea unei sinteze constructive, în care se îmbină diferite contribuții, care să fie supuse primirii comunităţilor locale şi care să asigure pe viitor climatul propice manifestărilor cu impact geopolitic, fără a induce sau a produce suspiciuni provocatoare. Biserica lui Hristos are nevoie de unitate deplină, mai întâi în sânul Europei unite pentru ca această unitate să poată fí promovată cu succes la nivel global, pornind chiar de la premiza că suntem cu toții creştini şi europeni, atitudine ce necesită un exercițiu spiritual de amploare menit să elimine barierele lingvistice sau concepțiile despre superioritatea unui popor față de altul. Misiunea ecumenică a Bisericii nu presupune aplatizarea culturilor şi nici uniformizarea manifestărilor culturale şi spirituale, ci acea unitate dată tocmai de diversitatea popoarelor după cum ne învață Sf. Apostol Pavel, atunci când vorbeşte despre poporul creştin: ,Nu mai este iudeu, nici elin; nu mai este nici rob, nici liber; nu mai este parte bărbătească şi parte femeiască, pentru că voi toți una sunteți in Hristos Iisus"(Galateni 3,28).

${ }^{6}$ Cf. E. LoRA, Reflessioni e suggerimenti circa il dialogo ecumenico, în Enchiridion Vaticanum . Documenti ufficiali della Santa Sede 1968-1970, Bologna, Ed. Dehoniane, 1976, p. 1619. 
$\mathrm{Nu}$ de puține ori Biserica este asemănată cu familia sau mai bine zis familia se aseamănă cu Biserica, tocmai pentru a sublinia şi mai mult importanța misiunii Bisericii în promovarea unui dialog al păcii familiale, asupra căruia să guverneze pronia divină, iubirea creştină, adevărul şi libertatea neîngrădită.

„Printre principalele aspecte ale lumii de azi se numără inmulțirea relațiilor reciproce dintre oameni, la evoluția căreia contribuie mult progresul tehnic contemporan. Totuşi dialogul frățesc dintre oameni nu-şi găseşte implinirea în acest progres, ci mai profund in comunitatea persoanelor, comunitate care pretinde un respect reciproc față de deplina lor demnitate spirituală. Revelația creştină favorizează intens promovarea acestei comuniuni între persoane şi în acelaşi timp ne călăuzeşte spre o înțelegere mai adâncă a legilor vieții sociale, pe care Creatorul le-a inscris în natura spirituală şi morală a omului"," .

Din această prospectivă, dimensiunea ecumenică (expresie demnă de unitate) constituie un aspect fundamental în viața Bisericii, de unde îşi trage originea, ba mai mult, toate elementele de adevăr şi de sfințenie care se găsesc în afara organismului ecleziastic sunt daruri proprii ale Bisericii lui Hristos, Cel ce îndemnă către unitatea deplină: „Ca toți să fie una, după cum Tu, Părinte, întru Mine şi Eu întru Tine, aşa şi aceş̧tia în Noi să fie una, ca lumea să creadă că Tu M-ai trimis" (Ioan 17, 21).

Punctul de plecare este planul de mântuire a lui Dumnezeu Întreit, care este proiectul iubirii Sale pentru istorie, ce se naşte în mod deosebit prin dăruirea Fiului, din partea Tatălui în Duhul Sfânt, prin evenimentul Crucii în folosul întregii omeniri: „Ínălţat pe cruce şi glorificat, Domnul lisus a revărsat pe Duhul făgăduit, prin care a chemat şi a adunat în unitatea credinței, speranței şi iubirii poporul

Conciliul Oecumenicum Vaticanum II, Constituția pastorală privind Biserica în lumea contemporană - Gaudium et Spes, partea I, Capitolul 2, paragraful 23, Roma (Catedrala Sf. Petru), 7 decembrie 1965. 
Noului Legământ - Biserica". . Poporul, care se naşte din darul Mântuitorului Răstignit pe Cruce şi Înviat a treia zi din Mormânt, este poporul unității în diversitate, al unităţii de identitate şi al diversităţii în întreita slujire a lui Hristos: pedagogică (ÎnvățătorProoroc), liturgică (Arhiereu) şi cârmuitoare-proniatoare (Împărat).

Unitatea Europei nu poate fi asigurată decât printr-o unitate de credință, cu atât mai mult cu cât este vorba de însăşi credința cea adevărată în Singurul şi Unicul Dumnezeu Cel Viu. Interesele geopolitice ale Uniunii Europene nu îşi pot găsi coerența fără unitatea pe care o aduce creştinismul prin Biserica lui Hristos cea Una, o altă abordare fiind sortită eşecului cu implicații ce pot deveni catastrofale. Biserica nu îndeamnă la sancţiuni şi nici la războiul oamenilor unii împotriva altora, ci doar la războiul împotriva răului din lume, pe care singuri ni-l facem, la dialogul păcii durabile, lipsită de şiretlicuri şi interese meschine. Această perspectivă defineşte şi mai mult sensul şi orientarea misiunii Bisericii spre dialogicitatea ecumenică în contextul geopolitic european actual.

Misiunea ecumenică a Bisericii este o opțiune fundamentală pentru cei botezaţi, deoarece este expresia identității ecleziale şi a proiectării de credință, adică a vieții fraterne şi a reconcilierii: "Nimeni, în Biserică nu se poate socoti un izolat". " Chemarea la dialog în vederea unității nu este împotriva libertăţii şi a identităţii personale, deoarece este proiectarea unității în diversitate. Ecumenismul este o vocație generală însă nu generică, pentru că se exprimă în mod istoric prin harismele şi ministerele fiecărui credincios. Ecumenismul reciprocității, pe de o parte, face ca Biserica să înainteze spre plinătatea unității ei şi, pe de altă parte, face să apară comuniunea care deja există în prezent şi care se exprimă în mod deosebit prin rugăciunea pentru unitate a creştinilor. Lauda, mulțumirea, mijlocirea comunităților ecleziale, arată că

${ }^{8}$ Conciliul Oecumenicum Vaticanum II, Decretul de ecumenism Unitatis redintegratio, Sesiunea V, Capitolul 2, Roma (Catedrala Sf. Petru), 21 noiembrie 1964, AAS 57 (1965) 90-107.

${ }^{9}$ G. Pattaro, Per una pastorale dell'ecumenismo. Commento al Direttorio Ecumenico, Ed. Queriniana, Brescia 1984, p. 201. 
unitatea este, înainte de toate, darul lui Dumnezeu Întreit, care este credincios promisiunilor sale; este venirea istorică şi eshatologică a iubirii sale eliberatoare şi creative.

Pe de o parte, ni se semnalează şi perspectiva evanghelică, conform căreia Euharistia este darul anticipat al unităţii, datorită cărui fapt actualmente este posibilă inter-comuniunea creştină, subliniindu-se că „participarea la har uneori o recomandă”, însă pentru practica vieții spirituale acest lucru trebuie să fie în concordanță cu bisericile locale, ca reprezentante ale Bisericii mamă.

Sinteza cu privire la problema inter-comuniunii nu este uşoară pentru că, a face din ea o practică obişnuită înseamnă a promova un ecumenism irenist, însă a-l evita în mod absolut în timpul pelerinajului spre deplina unitate înseamnă a ne încrede în mod exclusiv în capacitățile umane şi a nu ne da seama de necesitatea darului milostivirii şi al reconcilierii lui Dumnezeu. $\mathrm{Cu}$ toate acestea, alegerea postului euharistic este semnificativă pentru intolerabilitatea stării de divizare ${ }^{10}$.

Dialogul teologic favorizează între creştinii ecumenici o cunoaştere obiectivă reciprocă care comportă un schimb bogat şi un discernământ hermeneutic, pentru fiecare tradiție eclezială, între ceea ce este prioritar şi fondator şi ceea ce este o consecință şi o expresie istorică şi culturală.

Caracterul ecumenic este recomandat mai ales celor care lucrează în bisericile tinere, pentru că în această perspectivă evanghelizarea este mai eficace. $\mathrm{O}$ astfel de abordare a problemei ar putea duce la gândul unui „ecumenism strategic”, însă, în realitate, se subliniază că evanghelizarea confesionalistă este contradictorie misiunii Bisericii în contextul geopolitic european actual, deoarece nu promovează cauza Împărăției lui Dumnezeu, cauza fraternității şi solidarității, atenția față de alteritatea discretă şi respectuoasă, ci supunerea oarbă fără implicarea libertății, sentimentului şi voinței.

${ }^{10}$ G. Pattaro, Per una pastorale dell'ecumenismo. Commento al Direttorio Ecumenico, Brescia, Ed. Queriniana, 1984, p. 217. 
Hermeneutica teologică cere confruntarea „doctrinei” cu Cuvântul revelat al Sfintei Scripturi, printr-o critică a sa eliberatoare şi creativă, aşa după cum afirmă teologul Bruno Forte: „Aici stă frumusețea şi aici stă riscul actului hermeneutic, care a fost numit memoria periculoasă sau care trăieşte; riscul stă in posibilitatea, mereu amenințătoare, de a captura Cuvântul, de a absolutiza propria meditatie, de a obiectiviza ceea ce transcende orice reductie la obiect. Tocmai datorită acestui lucru memoria critică trebuie să fie permanent critică față de sine insuşi ${ }^{\prime}{ }^{\prime \prime}$

Pe baza perspectivelor teologice scoase în relief, misiunea Bisericii în contextul geopolitic european actual trebuie să afirme deplina angajare a Bisericii celei Una pentru a manifesta comuniunea deplină prezentă în Bisericile surori, respectând diversitatea lor „eliminând orice duh de rivalitate și neînțelegere". ${ }^{12}$ Sinteza unei limbaj dialectic ecumenic ne îndeamnă să evităm graba şi superficialitatea unei misiuni ecleziale în vederea unităţii, lăsându-ne conduşi de creativitatea Duhului Sfânt. Speranța unei misiuni ecumenice a Bisericii, fondată pe primatul lui Hristos faţă de Trupul Său mistic (Biserica), ar asigura promisiunea alianței milostive şi împăciuitoare cu umanitatea, care triumfă asupra contradicțiilor operativității umane şi orgoliilor de „primus inter pares”.

„Ca toți să fie una ... ca toți să creadă” sunt cuvintele Mântuitorului din ajunul Patimilor care-L vor conduce la moartea pe cruce „ca să adune laolaltă pe fiii lui Dumnezeu cei imprăştiaţi" (Ioan 11, 52) şi prin care Iisus se rugă pentru discipolii Săi şi pentru cei ce urmau să creadă în El în toate timpurile şi în orice loc. El s-a rugat şi pentru creştinii timpului nostru. A cerut Tatălui ca să fie „una”, uniţi între ei într-un mod ce depăşeşte orice putinţă de înțelegere: „După cum Tu Părinte eşti în mine şi Eu în Tine, aşa şi aceştia în noi să fie una" (Ioan cap. 17, v. 21).

${ }^{11}$ B. Forte, La teologia come compagna, memoria e projezia: Introduzione al senso e al metodo della teologia come storia, Milano, Paoline, 1987, p. 178.

${ }^{12}$ Conciliul Oecumenicum Vaticanum II, Decretul de ecumenism Unitatis redintegratio, Roma (Catedrala Sf. Petru), paragraful 18, 21 noiembrie 1964, AAS 57 (1965) 90-107. 
Unitatea, pe care Domnul o invocă pentru discipolii Săi, este înainte de toate comuniunea cu Dumnezeu. O comuniune reală care nu este numai sentiment, ci este sălăşluirea Lui în om şi asimilarea omului în Dumnezeu. Iar prin această misterioasă comuniune de viață cu Dumnezeu, prin care ne face participanți la natura sa prin harul necreat, rezultă comuniunea între creştini: ,cu cât vor promova şi vor trăi mai mult în practică uniunea creştinilor, cu atât mai mult vor învăta să ducă o viață mai conformă cu Evanghelia. Cu cât vor $f i$ uniți cu Tatăl, cu Cuvântul şi cu Duhul Sfânt, cu atât mai mult acțiunile sfinte şi simple vor spori relațiile fraterne reciproce, ${ }^{, 13}$.

Şi tot prin această perspectivă se înțelege strânsul raport pe care-L face Iisus între unitatea creştinilor şi progresul credinței în lume, exprimând soluția misiunii Bisericii în lumea contemporană, calitatea şi coerența credinței noastre în unicul Dumnezeu. Cuvintele lui Iisus Hristos ne readuc în centrul problemei ecumenice şi la locul ei esențial, indicând urgența de a restabilii unitatea comunităţii creştine în mod deplin şi armonios, astfel încât să se împlinească misiunea Bisericii de a-1 anunța tuturor oamenilor pe Mântuitorul Iisus Hristos.

Misiunea Bisericii în contextul geopolitic european actual subliniază şi importanța rugăciunii pentru refacerea unității. Acelaşi Iisus, Domnul, s-a adresat Tatălui pentru a-I cere să păstreze discipolii în numele Său şi să-i ,, sfințească prin adevăr"'(Ioan 17, 19), să toarne în ei aceeaşi iubire pe care Tatăl o are pentru Fiul, în şi prin Sfântul Duh.

Rugăciunea pentru unitate este un angajament al Misiunii Bisericii astăzi pentru condiția oricărui creştin. Dacă nu pot participa toți la diferite aspecte ale căutării unităţii (studii, dialog etc.), pot să se unească în insistența prin care invocă darul şi harul unității. O pot face parohiile, comunitătile religioase, în special cele cu viață contemplativă, persoanele în mod individual şi toți creştinii care sunt

13 Conciliul Oecumenicum Vaticanum II, Decretul de ecumenism Unitatis redintegratio, Roma (Catedrala Sf. Petru), paragraful 7, 21 noiembrie 1964, AAS 57 (1965) 90-107. 
angajați în această căutare comuniunii universale, care provine de la botezul creștin comun. Unitatea, la care sunt chemați creştinii, este unitatea desăvârşită. În fața creştinilor stă idealul deplinei unități de credință, de viață sacramentală şi de articulație organică a unirii ecleziale.

Cuvintele unui tată sunt întotdeauna prețioase, fiindcă trebuie să crezi celui ce-ți spune cu iubire. Dar dacă, înainte de a muri, tatăl spune ultimele sale cuvinte, acestea rămân gravate în sufletul fiilor săi şi valorează cât toate celelalte cuvinte la un loc; sunt testamentul lui. Iubirea paternă nu este nimic față de iubirea lui Dumnezeu. Şi Dumnezeu făcut om, Iisus, a vorbit şi El are un testament: „, Ca toți să fie una" (In 17,21). Cine-şi consacră viața unității, trăieşte în inima lui Dumnezeu.

Creștinii au avut întotdeauna conștiința responsabilității lor față de nefirescul stării de dezbinare. De aceea, în decursul istoriei nu au încetat încercările de unire. Secolul al XX-lea a marcat, însă, o intensificare fără precedent a eforturilor creştinilor pentru restabilirea unității. S-a creat un spirit ecumenic, apoi o mişcare ecumenică. Foarte repede, aceste eforturi s-au materializat în crearea de organisme creştine internaţionale, regionale şi locale sau în instituționalizarea dialogurilor bilaterale sau multilaterale. $\mathrm{Cu}$ alte cuvinte, Biserica şi-a amplificat misiunea sa vocaţională.

Toată lumea ştie de existența Consiliului Ecumenic al Bisericilor, înființat în 1948, de Conferința Bisericilor Europene, înființată în 1959, de existența Consiliilor Ecumenice naționale sau a Conferințelor Interconfesionale. Lucrurile aveau să avanseze şi în spaţiul relaţiilor dintre ortodocşi şi catolici. În 1965, Patriarhul Athenagoras al Constantinopolului şi Papa Paul al VI-lea ridicau concomitent anatemele aruncate reciproc în 1054, pentru ca în 1980 să debuteze dialogul teologic oficial între cele două Biserici surori.

Frecvența dialogurilor, a întâlnirilor intercreştine din ultimii cincizeci de ani şi mai bine, a fost şi continuă să fie atât de mare, încât pe drept cuvânt secolul al XX-lea a fost numit „secolul ecumenismului”. Unitatea tuturor creştinilor este un deziderat 
declarat al tuturor Bisericilor şi confesiunilor creştine, conştiente de imperativul şi adevărul poruncii ,,ca toți să fie una".

În ultimii ani ai secolului $\mathrm{XX}$, ecumenismul a fãcut paşi uriaşi, a parcurs distanțe până mai ieri de negândit, ajungând la rezultate excelente, ce au la bază acea „Cartă a unității”, contribuind fără echivoc la consolidarea Uniunii Europene aşa cum o ştim astăzi, promovând şi participând activ la dialogul păcii reconciliante plină de „inspirație şi speranţă ${ }^{\prime \prime}$. Reflexia şi angajamentul ecumenic impun omului o muncă grea de purificare intelectuală, în sensul că el trebuie să înlăture acele obstacole care împiedică primirea în profunditate a Cuvântului, ca de exemplu: prejudecățile de orice natură, schemele mentale şi toate acele opinii sumare - rodul unei determinate formări culturale şi de lene mintală -, care fac posibil riscul de a deveni incapabili de a înțelege Cuvântul, Cel care provoacă, luminează şi susține drumul convertirii şi al păcii unificatoare. Iată misiunea Bisericii către strategia geopolitică europeană perfectă, de care Uniunea Europeană ar trebui să țină seama, promovându-şi realitatea existențialistă pe măreția fără egal a învățăturii Cuvântului lui Dumnezeu.

Convertirea cugetului, în contextul geopolitic european actual, trebuie să-l facă pe creştinul european să conştientizeze că doar Cuvântul lui Dumnezeu ne eliberează de închiderea noastră mintală şi aprinde dorinţa noastră de unitate, pentru a ne împinge la o adevărată activitate misionară în plan european, ecumenică, profundă, condusă în umila cercetare comună a unicului adevăr de credinţă $^{15}$, care apoi este Hristos prezent în Biserica sa şi în orice om. ,"Dorința de unitate se naşte şi creşte din abnegația de sine însuşi ", 16 . Această abnegație nu este desigur, rodul acelei false umilințe care

${ }^{14}$ Cf. Papei Ioan Paul al II-lea, a douăsprezecea scrisoare enciclică $U t$ Unum Sint (Latin: 'That they may be one'), paragraful 25, 25 mai, 1995.

15 Cf. Y.M. Congar, Proprietà essenziali della Chiesa, în Mysterium Salutis, VII, Brescia, Queriniana, 1972, p. 433.

${ }^{16}$ Conciliul Oecumenicum Vaticanum II, Decretul de ecumenism Unitatis redintegratio Roma (Catedrala Sf. Petru), paragraful 7, 21 noiembrie 1964, AAS 57 (1965) 90-107. 
duce omul la închiderea în sine însuşi, şi nici aceea integritate inutilă de penitențe [...], ci atitudinea spirituală ce-l aşează pe om intr-un drum pe care trebuie să-l realizăm mereu, reamintindu-ne de ceea ce sfinții au avut mereu în conştiință: ,până la sfârşit trebuie, cu umilință şi constanță, să reîncepem de la capăt ${ }^{, 17}$.

În fața lui Dumnezeu omul trebuie să moară pentru el însuşi, pentru a se putea deschide la plinătatea darurilor lui Dumnezeu. Prin intermediul acestui raport al omului cu Dumnezeu, în om şi în Biserică izvorăşte dorința de a merge pe căile unităţii şi păcii, cele două coordonate esențiale ale misiunii Bisericii, mai ales în contextul geopolitic european al zilelor noastre: ,Dorința unității se naşte şi se dezvoltă din revărsarea liberă a iubirii ${ }^{\prime \prime}$.

Vechea maximă repetă că "nici un om nu este o insulă", nimeni nu s-a născut pentru sine însuşi ci pentru alții şi pentru Altul, adică pentru Dumnezeu. Acest Absolut de neatins şi de neajuns a venit să-l întâlnească pe om, în persoana unui Om, Hristos; în Hristos, Dumnezeu S-a făcut prezent şi vine să întâlnească pe orice om.

Omul este aşadar chemat, prin vocaţie divină să iasă din el însuşi pentru a merge să-L întâlnească pe Dumnezeu şi să-i întâlnească pe ceilalți oameni ca el. Va putea să realizeze aceasta numai în iubirea lui Hristos, prin acea iubire pe care Duhul o insuflă în inima fiecărui credincios, dându-i aşadar să poată muri pentru el însuşi, pentru a putea trăi, iubind pe aproapele în viața de comuniune cu Dumnezeu. Convertirea evanghelică eliberează în om această iubire, până ce omul poate să creeze o fraternitate, să fie frate pentru altul, dorința ce devine spiritul comuniunii şi unității fiilor lui Dumnezeu. Într-o asemenea perspectivă, Europa unită nu va da greş.

Iubirea eliberează omul de închiderea în el însuşi şi îi aprinde dorința întâlnirii şi a comuniunii. Misiunea europeană a Bisericii

${ }^{7}$ Cf. S. Bonaventura, Legenda Maior XIV, Milano, Ulrich Scinzenzeler, 1495, 1: FF 1237.

${ }^{18}$ Conciliul Oecumenicum Vaticanum II, Decretul de ecumenism Unitatis redintegratio, Roma (Catedrala Sf. Petru), paragraful 7, 21 noiembrie 1964, AAS 57 (1965) 90-107. 
găseşte în iubirea fraternă rădăcina şi izvorul său primar. Din toate câte s-au spus, reiese bine că „a face misiune în Europa unită a zilelor noastre" derivă numai din , a fi europeni cu toții în spiritul Evangheliei creştine", adică trăind convertirea evanghelică în Duh, şi cu ajutorul acelei fraternităti în care Duhul ne-a chemat să-L urmăm pe Hristos ${ }^{19}$.

Bisericile din Răsăritul european, în general, se exprimă în mod critic față de cultura modernă tipică lumii occidentale, cu criza sa de valori, şi se tem de această întâlnire. Uneori această critică se referă şi la comunitățile creştine din Occident, care s-ar fi acomodat revărsării seculare şi relativiste.

Creştinii, deşi sunt înrădăcinați în propria Biserică care i-a generat spre credință, sunt chemați să descopere misterul comuniunii, din care izvorăşte frățietatea, redescoperită de ei dincolo de granițele confesionale. În măsura în care ei se vor simţi membre ale unicului trup al lui Hristos, se vor putea face purtători ai unei voci active în bisericile lor, pentru ca frățietatea regăsită între cei botezați să-i cuprindă deplin şi pe toți cei hirotoniţi şi responsabili ai instituțiilor eclesiale ale oricărei confesiuni creştine. Aceştia din urmă, înainte de a avea misiunea instituţională de a servi şi reprezenta în mod oficial propria biserică, sunt mereu creştini ce-şi trăiesc propriul Botez şi chemarea de a experimenta relația cea nouă a frăției regăsite. Această regăsire a fraților poate consolida la modul sublim orientarea geopolitică a Europei, ferind-o de căderile fireşti ce-i pun la încercare însăşi existența. Orientarea statului european către realitatea evanghelică a creştinismului european i-ar asigura aceea continuitate de care nu s-a bucurat nici un imperiu omenesc, ştiut fiind faptul că doar Împărăția lui Dumnezeu este veşnică.

Având în vedere elementele comune care îi unesc pe creştini şi distanța ce trebuie să fie parcursă până la refacerea deplină şi vizibilă a comuniunii, creştinilor de astăzi le revine misiunea de a pregăti terenul prin rugăciune, dialog, cunoaştere şi respect reciproc.

${ }^{19}$ I. Mărtincă, Duhul Sfânt, Ed. Universității din București, 2006, p. 117. 
Dată fiind situația actuală a societătii, în care s-a dezvoltat cultura şi se amestecă tot mai mult popoarele şi obiceiurile, dialogul interconfesional şi interreligios a devenit absolut necesar: „astăzi, înainte de toate, trebuie să ştim să conviețuim cu cei diferiți de noi, chiar în domeniul religios. Dialogul interreligios nu înseamnă a ceda în fața erorii; nu înseamnă acceptarea unui sincretism religios; nu este toleranţă naivă şi superficială. Dialogul respectă conştiințele; dialogul recunoaşte valorile fiecărei religii; dialogul, mai presus de toate, se angajează în mărturia personală, în aşa fel încât să influenţeze spiritual şi să comunice nostalgia adevăratei şi unicei religii, cea voită de Dumnezeu Însuşi. În acest sens, înapoi nu se mai poate merge: Adevărul revelat, cu tot conținutul său religios şi moral, şi angajarea pentru Adevăr rămân sarcina şi misiunea Bisericii şi a fiecărui creștin. În ceea ce privește mântuirea veşnică a celor care nu cred (sceptici, agnostici, atei şi chiar antiteişti) şi a celor care cred diferit, trebuie, în mod necesar, să o încredințăm total dreptății şi bunătăţii Celui Preaînalt: „Biserica se vede pe sine ca Sacrament, adică semn şi instrument al unirii intime cu Dumnezeu şi al unității intregului neam omenesc. Aşadar, se vede pe sine în relație cu intreaga mare familie umană, aflată în creştere constantă. Se vede pe sine în dimensiuni universale. Se vede pe sine pe căile ecumenismului, adică ale unității tuturor creştinilor, pentru care Hristos însuşi s-a rugat şi care este de urgență indiscutabilă în vremea noastră. Se vede pe sine şi în dialogul cu adepții religiilor necreştine şi cu toți oamenii de bunăvoință. Un asemenea dialog este un dialog al mântuirii, care trebuie să slujească şi păcii în lume şi dreptății între oameni" ${ }^{, 20}$.

Astăzi, în zorii celui de-al treilea mileniu, nu putem da înapoi ceasul istoriei. Putem însă să interpretăm diferite evenimente din cel de-al doilea mileniu în lumina primului mileniu, pentru a deschide porțile celui de-al treilea mileniu.

${ }^{20}$ Ioan Paul al II-lea, Planul lui Dumnezeu. Decalog pentru mileniul III, București, Editura Enciclopedică, 1999, p. 187-188. 
O receptare asemănătoare din partea Bisericilor încă nu s-a petrecut. Această receptare sau primire nu implică o acceptare mecanică sau o supunere a unei Biserici față de alta; ea ar implica, mai bine zis, un proces creativ şi dinamic de cunoaştere şi primire în propria tradiție. Aceasta ar îmbogății tradiția comună celor două Biserici surori şi le-ar conferi cel mai înalt grad de unitate şi de independență, care actualmente le lipseşte. Întreaga Biserică sau Biserica cea Una s-ar întoarce la respirația prin cei doi plămâni ai săi, oferind stabilitate şi durabilitate inclusiv statului politic european. Aceasta înseamnă că, integrând cealaltă tradiţie în cea proprie şi viceversa, s-ar putea ajunge la diferite forme şi expresii în exerciţiul slujirii hristice, aşa cum s-a petrecut în primul mileniu creştin ${ }^{21}$.

A venit vremea să se sfârşească împărțirea confesională şi să se iniţieze şi contureze dialogul, reconcilierea şi unitatea creştină pe plan european şi internaţional. Unitatea dintre Biserici vine şi reuşeşte să susţină unitatea geopolitică europeană (şi implicit Uniunea Europeană în granițele sale lărgite), cu atât mai mult cu cât, deşi trăim în mileniul III, asistăm cu nepăsare la asasinarea creştinilor în numele unei false iluzii: ,, Suntem chemați să arătăm cu cuvintele şi gesturile de azi, bogățile imense păstrate de Bisericile noastre în tezaurul traditiei lor. Avem totul în comun şi în comun mai ales dorința sinceră de unitate ${ }^{, 22}$.

$\mathrm{Nu}$ poate exista o Europă unită decât în unitatea dată de creştinii de pretutindeni, de aceea strategia geopolitică a Europei, ce trebuie să includă creştinii de pretutindeni, indiferent de culoare, naţionalitate şi sex. Europa creştină nu se poate limita la un anumit spaţiu ci trebuie să lupte pentru protejarea interesului său creştin, nu prin forță ci cu înțelepciunea biblică. Dacă statul european nu conştientizează aceste aspecte determinante, patronate de realitatea creştină a misiunii Bisericii în lume, atunci spațiul european riscă să devină o bombă cu ceas, al cărei tic-tac se apropie de implozie.

${ }^{21}$ Cf. J. Meyendorff, Orthodoxy and Catholicity, New York, 1966, p. 49-78.

${ }^{22}$ Ioan Paul al II-lea, Cuvântul papei Ioan Paul al II-lea rostit în limba română la sosirea în România, în Papa Ioan Paul al II-lea Binecuvântează România, 7-9 mai, București, 1999, alineatul 23. 


\section{Bibliografie}

1. Biblia sau Sfânta Scriptură, București, Ed. Institutului Biblic şi de Misiune al Bisericii Ortodoxe Române, 2001.

2. Anghelescu. G.F., Papa Ioan Paul al II-lea: un veritabil model pentru dialogul interreligios al secolului al XXI-lea, în I. Bisoc, Un buchet de laude pentru papa Ioan Paul al II-lea, Roman, Serafica, 2006.

3. Catehismul Bisericii Catolice, București, Ed. ARCB, 1993.

4. Consiliul Pontifical pentru Promovarea Unităţii Creştinilor, Indreptar pentru aplicarea principiilor şi normelor cu privire la ecumenism, Iași, Editura „Presa Bună”, 2001.

5. Dancă, Wilhelm, Sfântul Duh şi unitatea în credință, în „Dialog Teologic”, nr. 1, Iaşi, Ed. Presa Bună, 1998.

6. Evdokimov, Paul, L'ortodossia, Bologna, Il Mulino, 1965.

7. Lossky, Vladimir, Introducere în teologia ortodoxă, traducere de Lidia și Remus Rus, Bucureşti, Editura Sophia, 2006.

8. Mărtincă, Isidor, Duhul Sfant, Ed. Universității din București, 2006.

9. Popescu, Dumitru, - Ică, Ioan, Biserica Ortodoxă Română şi integrarea europeană, în "Biserica în misiune. Patriarhia Română la ceas aniversar", Bucureşti, Edit. IBMBOR, 2005.

10. Stăniloae, Dumitru, Iubire creştină, Galați, Editura Porto Franco, 1993.

11. Idem, Teologia dogmatică ortodoxă, volumul 1, București, Editura Institutului Biblic și de Misiune al Bisericii Ortodoxe Române, 1996.

12. Zizioulas, Ioannis, Ființa eclesială, București, Editura Bizantină, 1996.

13. World Council of Churches (Consiglio mondiale delle Chiese), Désordre de l'homme et dessein de Dieu. La première Assemblée du Conseil Oecuménique des Eglises, Amsterdam 1948, Delachaux-Niestlé, Neuchâtel 1949. 